\title{
Chymotrypsin-Like Elastase Family Member 1
}

National Cancer Institute

\section{Source}

National Cancer Institute. Chymotrypsin-Like Elastase Family Member 1. NCI Thesaurus.

Code C115178.

Chymotrypsin-like elastase family member 1 ( $258 \mathrm{aa}, \sim 28 \mathrm{kDa}$ ) is encoded by the human CELA1 gene. This protein is involved in protein hydrolysis. 